Journal of Social Sciences 7 (2): 209-212, 2011

ISSN 1549-3652

(C) 2010 Science Publications

\title{
A Comparative Study of the Development Model in Education and Religion Management Process between Thailand and Lao
}

\author{
Songkoon Chantachan \\ Department of North Eastern Arts and Culture, \\ Maha Sarakham University, Maha Sarakham, 44000, Thailand
}

\begin{abstract}
Problem statement: The monks' education was a foundation for national development. The objectives of this research were: (1) to study historical background and development of model and process of management in education and religion between Thai-Lao, (2) to study and compare the model of management in education and religion of Thai-Lao and (3) to find guidelines for collaboration in management of education and religion. Approach: The area in Thailand and Lao People’s Democratic Republic, collecting data from 3 districts including: Luang Prabang, the wall of Vientiane City and Sawanked (Suwanked). The samples were the monks, novices and related persons, total of 300 persons. Qualitative Research Methodology was administered. The instruments using in this study consisted of: questionnaire, observation form and focus group discussion, analyzing based on the objectives. The research findings were presented in descriptive analysis. Results: (1) the development in general course study of Thailand and Lao People's Democratic Republic, started at the temple, the monks acted as both of teachers teaching material and dharma and supporters. Only boys had their opportunity to study both of general filed and Bali Field of study simultaneously. In some institutes, foreign languages were added for usefulness for studying in higher level as well as working, (2) for model and process of education and religion, both countries had similar aspects of educational policy, for example, educational quality development, enhancement for people and organization to participate in educational management. For the difference, Lao People's Democratic Republic gave an importance to the search for support from foreign countries while policy of Thailand focusing on being center of education in Indo China Country Group and (3) for collaboration in development for education and religion of Thai-Lao, Thai should help Lao People's Democratic Republic in education both of youth and monks. The bureaucratic work units related to education both of direct and indirect ones by offering scholarship in higher education level in order to develop relationship for knowledge sharing. For monks' education, Lao monks should be supported for studying in monk college of Thailand with campuses all over country especially in Isan Region, so that the sustainable relationship would exist between 2 neighborhood countries. Conclusion/Recommendations: Education was an integral factor in national development. For the monks' education, it should be implemented in aligned with each other since both countries had faith in Buddhism as major religion in order to help in developing the virtue and morality simultaneously with national growth.
\end{abstract}

Key words: Education and religion, academic field, sustainable development, monks' education

\section{INTRODUCTION}

The government of Loa People's Democratic Republic issued National Educational Law emphasizing on compulsory education in Elementary Education, education, supervision and people's quality of life improvement especially for various women tribes. However, the government faced many obstacles in implementation for success. Therefore, the support from foreign countries was needed. As it could be seen that Lao People's Democratic Republic, borrowed money from World Bank, Asia Bank and request for support from foreign countries as well as NGOs for more than 100 dollars in order to develop the education in aligned with foreign countries more than 20 projects.

In addition to the educational system in school, Lao people still were able to choose to study for life progress through Buddhism. The education offered opportunity for poverty people particularly those who lived in remote area. The charter of Lao in 2008, Section 30, stated that "citizen had their right and freedom to believe or didn't believe in religion”. But, in fact, people who were Buddhists using opportunity in studying. There were 3 levels of Lao educational 
system: Elementary Level, Secondary Level and Higher Education Level. In each level, there were shortages of school and teacher such as in Higher Education Level, there was only one district in the country: University developing the monk, Tatluang Temple and Ongtue Temple, total of 2 institutes situated at Vientiane City. Therefore there was an improvement by offering classroom for novice studying together with both of boys and girls in Elementary School such as Luangnam District in Northern Region of Lao. It was also found that some of monk activities were different from what being seen in Thailand.

According to the above, could be viewed that the model and educational process and religion of Lao, still needed for help from neighborhood countries very much. Thailand had policy to be center of education between Thai-Lao which was very important since it would be major foundation in creating sustainable collaboration on education and religion between the countries. It could be understood that the present climate being able to provide support for collaborating in many aspects between Thai-Lao. Besides, the collaboration with attempt to perform in various patterns, would affect trust which was important in relationship of Thai-Lao. The education, religion and academic should be basic of good cooperation since the area of education, religion and academic had no benefit, little if any. This academic field, should be indicator for policy makers both from public sector and private sector involving in contacting and making relationship for educational development as relative neighborhood countries. The academic field would act as a buffer of relationship if there were some tensions while the academic field in education and religion needed to open their mind and compromise by viewing benefit for people as major aim. To have intensive knowledge with conscious was a good thing for academic field in education and religion which would lead to understanding and friendship of both countries.

\section{MATERIALS AND METHODS}

The research area was in Lao People's Democratic Republic. Data were collected in 3 districts: North Region District, including Luang Pra Bang, Central Region including the wall of Vientiane City and South Region including Sawannaked District (Suwanked). For the research area in Thailand, data of the field study in education and region were collected from 7 provinces of Isan Region, divided into 2 provinces of Upper Part of Isan, 3 provinces of Central Part of Isan and 2 provinces of Lower Part of Isan. Data were collected by the survey, observation, interview, focus group discussion and workshop. The samples were selected by Purposive Random Sampling, 300 persons, including 200 monks and 50 persons relating to educational management of the monks and 50 general informants.

\section{RESULTS}

- For development of education in general courses of Thailand and Lao People's Democratic Republic, started from the temple by the monks responsible in both of teaching material, dharma and supporters. The boys cold learn from both og general book and dharma books simultaneously by studying foreign languages in order to use for communicating in trading and diplomat with foreign countries. In education, Buddhism in both of Thailand and Loa People's Democratic Republic aimed to inherit religion through the boys for ordaining and studying. Later on, Thailand had development in education of monks to the degree level. There were 2 major higher education institutes: Mahamakut Royal Institute and Maha Chulalongkorn Royal Institute whereas Lao People's Democratic Republic had only Monk College managing the monks' education in high level of certificate. It was supported by Phad et al. (2010) so, the education and quality of life development were very important. Furthermore, the cultural management, the model obtaining from workshop found that the temple should be origin in transferring knowledge of religion and Thai good culture for people coming to temple so that they could gain knowledge and apply knowledge into practice in their way of life based on their belief It was supported by Saeng-Ngam (2009) To renovate the custom of sprinkling water onto the pagodas, the traditional practice initiated by folk wisdom and those who believed would result in a spiritually intricate interrelation/involvement between human being and historical/archeological sites. Such belief resulted in the conservation of the ancient remains. Owing to The mythical folklore the God ghost/spirit insisted on dwelling in the ancient site. The folks called him "God ghost/spirit Hong Daeng See Ha Rat" With respect to this belief. There existed, on the one hand, a common sense of paying respect/homage to the historical sites. The worshippers, on the other hand, became amicable

- For model and educational process and religion, both countries had similar policy of education in many aspects, for instance, the educational quality development, support for people and organization to participate in educational management. For the 
difference, the approach of Lao People's Democratic Republic, was to give an importance to the search for support from foreign countries while the educational policy of Thailand focusing on being educational center of in Indo China Country Group

- $\quad$ For collaboration in model development and study process in religion of Thai-Lao, Lao People Democratic Republic should be supported in education both of the youngsters and monks. The related bureaucratic work units both directly and indirectly, should provide scholarship in higher education in order to make relationship for knowledge sharing and faith development. For the monks' education, Lao monks should be promoted to study at Monk College in Thailand which consisted of more than 30 campuses especially in Isan Region including 8 colleges: Roi-ed, Loei, Nongkai, Ubonrachatani, Surin, Nakonpanom, Khon Kaen and Nakonrachasima. In addition, there was one more Nun College: Mahapachabodee Nun College supported by the Supreme Patriarch, Mahamakut Royal Collage in order to cause sustainable relationship for both of 2 neighborhood countries

\section{DISCUSSION}

- Thailand and Los People's Democratic Republic were relative countries with connected border for thousand kilometers, including similar educational and religion development in many parts. For differences, caused by political and governmental situations. Buddhism of both countries was trusted on by them as a principle of faith whereas the temple and monks were the centers of mind as well as the building of various permanent objects and public benefit activities for community. The monks and villagers collaborated in management for creating prosperous temple and city

- Furthermore, both countries were similar in that the community development. The monks would be very good trust for them by preaching or leading the developers to understand right, duty and occurred problem and guidelines for problem solving which would pass process of education. It was supported by Chaiyod (2000) study the analysis and development of educational model and community for sustainable development. The findings could be concluded as follows: (1) for problems of sustainable development in community, they were caused by environmental problems affected by socio-economic development.
As a result, the community as social system lost its equilibrium. The existed issues were used as modes for problem solving by allowing the community participation in planning and managing goal leading to practice guidelines and (2) there were 2 models of community study model for sustainable development as: Community based model initiated by community and institute based model initiated by outside work unit

\section{CONCLUSION}

- For education, Thailand and Lao People's Democratic Republic had viewpoint agreement of educational system and management model, in many aspects whether the educational quality, decentralization in education, participation in allowing every sector manage the education. However, Thailand extended education in higher education level very much especially during the 9th issue of National Educational Developmental Plan, including various fields of study both of open system and closed system. Therefore, Lao People's Democratic Republic should be supported by sharing and providing educational scholarship in Bachelor's Degree and Graduate Study, project for youth and students who had good conduct and selected by the government of Lao's People Democratic Republic, so that the students would come to study and stay with Thai volunteer family, especially in Isan Region with higher educational institutes in order to develop human resource aligned with socio-economic development and good relationship between the two countries

- For public sector, Thailand had many work units with educational management role both direct and indirect ways. So, the public sector should establish staff developmental plan in neighborhood countries in order to create sustainable relationship, for instance, provision of scholarship in diplomat political science, science, technology in medicine and public health. This kind of staff development would be congruent with government policy in education to be educational center in neighborhood country group. Many work units would establish Memorandum of Understanding (MOU) for creating certainty and clearness in shared implementation as well

- For education of the monk, Thailand had 2 monk colleges and more than 30 Campuses. Therefore, the monks in Lao People's Democratic Republic, who wanted to study in higher level since Lao didn't have educational institute for the monks. 
Besides, the ladies who were interested in Dharma in Loa (Nun) should be allowed opportunity in studying at Mahapachabodee University in the Supreme Patriarch Support of Mahamongkut Royal University

\section{REFERENCES}

Chaiyod, I., 2000. Development of community education model for sustainable development. Ph.D. Thesis, Chulalongkorn University, Bangkok, pp: 253. http://www.eurojournals.com/ejss_10_3_12.pdf
Phad, P., W. Siltragool and T. Panthachai 2010. Suitable management model for economic, social and cultural development derived from beliefs and rites on Prabuddha southern in Chachoengsao province. J. Soc. Sci., 6: 4-7. DOI: 10.3844/jssp.2010.4.7

Saeng-Ngam, A., S. Chantachon and P. Ritthide, 2009. The organization of cultural tourism by the community people in the region of Toong Kula Rong Hai. J. Soc. Sci., 5: 342-347. DOI: 10.3844/jssp.2009.342.347 